\title{
Accounting
}

\section{Does bank capital affect profitability and risk in Vietnam?}

\author{
Van Dung $\mathrm{Ha}^{\mathrm{a}^{*}}$
}

\begin{tabular}{l}
${ }^{a}$ Banking University of Ho Chi Minh \\
\hline C H R O N I C L E \\
\hline Article history: \\
Received October 242019 \\
Received in revised format \\
December 272019 \\
Accepted February 282020 \\
Available online \\
February 28 2020 \\
\hline Keywords: \\
Profitability \\
Risk \\
Banks \\
Capital \\
Loans \\
Equity \\
\hline
\end{tabular}
\begin{abstract}
A B S T R A C T
In this paper, we attempt to answer the question of whether or not bank capital affects profitability and risk. The paper forms an unbalanced panel with 354 observations using both data of 35 banks over the period 2007-2018. Two-step GMM is used to estimate the impacts of bank capital on profitability and risk in order to eliminate endogeneity and serial correlation issues. As a proxy of bank capital, the bank equity ratio, and equity level are used. Return on assets (ROA), return on equities (ROE), and net interest margin (NIM) are used to measure bank profitability, whereas nonperforming loan ratio and loan loss reserve ratio are used to measure bank risk. Bank capital displays significant impacts on profitability, which is measured by ROA and ROE, whereas capital shows no impact on bank NIM. When the loan loss reserve ratio is considered as proxy of bank risk, bank capital does not affect bank risk. The equity ratio, the proxy of bank capital, displays significant negative impacts on risk, whereas the equity level, the other proxy of bank capital, shows positive impacts on bank risk.
\end{abstract}

\section{Introduction}

During the economic boom in the period 2006-2007, the exploitation of exchange market developed the new banks as well as the expansion of the existing banks in Vietnam, especially the private commercial banks. However, the economic growth was reduced by the economic recession during the period 2009-2011, and banks were struggling because of their small size of capital. In this period, the income of banks reduced sharply because they had to raise their reserve and faced more challenges in controlling nonperforming loans and increasing capital (Dimitrios et al., 2010; Alper \& Anba, 2011). In addition, Vietnam has faced many challenges in economic performance after becoming a member of WTO in 2007. According to the agreement of WTO, Vietnam has to open the financial market for foreign investors, which led to the competition in the financial sector. The competition becomes more severe in the presence of $100 \%$ foreign capital banks. This leads to higher demand in the service quality as well as larger capital in the banking sector. Therefore, increasing the capital of commercial banks not only fulfills the requirements of the State Bank of Vietnam (SBV) but also meets the needs of these banks in order to ensure credit growth as well as low operating risk. However, an increase in bank capital may also affect bank profitability and risk in Vietnam. Until recently, most studies have been conducted in developed economies such as the United States and Europe as compared to less developed economies such as Vietnam. After the global financial crisis in 2008, the Basel Committee on Banking Supervision (BCBS) introduced Basel III for enhancing supervision and risk management in the banking industry. In order to consolidate the procedure of risk management in the banking industry, Basel III introduces new issues related to bank capital, rate of capital, and liquidity. In the period 2007-2018, bank equity has increased with an average of $17.2 \%$ per year in Vietnam. Concurrently,

* Corresponding author.

E-mail address: dunghv@buh.edu.vn (V.D. Ha) 
bank profitability and risk also fluctuated during this period. The answer to the question if an increase in the capital can promote profitability and can reduce the risk is important for policymakers. Many studies on this subject have been carried out so far but not in Vietnam, and thus this paper attempts to answer the question if bank capital has any impact on profitability and risk in Vietnam.

\section{Literature review}

Some of the studies have focused on the impacts of bank capital on bank profitability and risk. It has been observed that the impacts of capital on bank profitability are still inconclusive (Muda et al., 2013; Jafari \& Alchami, 2014). During the period 1998-2002, Athanasoglou et al. (2005) investigated determinants of the profitability of 65 banks in the South and East Europe. The equity rate was used to measure bank capital, whereas ROE and ROA were used to measure bank profitability. The results of the random effect model revealed that capital exhibited positive impacts on bank profitability (in both ROE and ROA). The results further revealed that financial systems in the South and East Europe have not reached the perfect capital market, therefore when banks increase their capital the cost expectation of finance difficulty decreases. Increasing bank capital also indicates better bank output. In another study, Flamini et al. (2009) examined factors that affected bank profitability in 41 economies in Sub-Saharan Africa. Based on data from 389 commercial banks from the period 1998 to 2006, the study used the random effect model and concluded that bank capital exhibited a positive impact on profitability. Berger (1995) also supported the positive impacts of bank capital on profitability. In other studies, however, the effects of bank capital on profitability are unclear. In one of the studies, Lee and Hsieh (2013) used the generalized method of moments (GMM) for examining the impact of bank capital on profitability of 42 banks in Asia from the period 1994 to 2008. The rate of equity on the total assets was used to measure bank capital, whereas ROA, ROE, NIM were used to measure bank profitability. The impacts are ambiguous, which depend on the income level of a country. Bank capital showed positively significant impacts on profitability in low-income economies, whereas the impacts were observed to be insignificant in high-income economies. Altunbas et al. (2007) reported that capital shows negative impacts on the profitability of banks in 15 European economies from the period 1992 to 2000 . A higher capital rate in commercial banks would result in a lower rate of profitability, whereas the capital rate positively affected the profitability of cooperative and saving banks. The fact that higher capitalization would generate lower bank profitability was supported by Goddard et al. (2013). In this paper, the dynamic model was used to investigate the determinants of bank profitability in eight European countries from the period 1992 to 2007 and reported that higher bank profitability would result in bank efficiency and diversification. Moreover, it has also been reported that higher bank capital would result in lower profitability of banks. Furthermore, the negative impact of bank capital also indicated that the opportunity cost of capital would decrease the owner profit.

The impacts of bank capital on risk led to ambiguous conclusions in the literature (Nguyen \& Le, 2016). Some of the researchers indicated positive impacts of bank capital on risk, whereas others indicated negative effects. A sample of 181 commercial banks of Europe was used by Iannotta et al. (2007) from the period 1994 to 2004. According to the results, the equity rate showed positive impacts on bank risk. Based on the minimum capital requirement of the Basel Committee, the implication was that banks with higher equity rate had relatively high-risk capital portfolio. According to Lee and Hsieh (2013), the level of impacts of bank capital on risk depends on the types of banks and the development of economies. Bank capital showed negatively significant impacts on risk in commercial and cooperative banks, whereas these impacts showed no significant impact on risk in investment banks. In relatively high-medium economies, bank capital negatively affected risk but this effect was also found to be negative in low-income economies. According to Ayaydin and Karakaya (2014) who used a sample of 23 commercial banks from the period 2003 to 2011, the impacts of bank capital were found to be different depending on how bank risk was measured. Bank capital positively affected risk when bank risk was considered as loan loss reserves or as variance of return on assets. The existence of regulatory hypothesis might be the primary reason for this positive impact wherein the policymakers often encouraged commercial banks to increase capital in accordance with bank risk. However, bank capital showed negative impacts on risk when the variance of return on equity was used as bank risk, which might be resulted from the moral hazard hypothesis. According to this hypothesis, banks with a lower capital rate often had high-risk loans. Another study of Jabra et al. (2017) applied the two-step GMM (Doytch \& Uctum, 2011) on 174 commercial banks and 23 investment banks in BRICS economies (Brazil, Russia, India, China, and South Africa) from the period 2004 to 2012. Separating the research period into two subperiods, namely, before economic crisis 2007 (pre-crisis) and after economic crisis (post-crisis), the study showed that bank capital, measured by the rate of equity on the total assets, exhibited negatively significant impacts on risk of commercial banks (measured by credit risk) in two subperiods. The same negatively significant impacts of investment bank capital on risk could be found in the postcrisis period, whereas no significant impacts of bank capital on risk were observed in the pre-crisis period. In sum, all studies reported that the results of the impacts of bank capital on profitability and risk are inconclusive. Finally, the conclusion is consolidated in this study contributing to the empirical literature of the bank industry.

\section{Methodology}

A sample of 354 observations of 35 commercial banks in Vietnam from the period 2007 to 2018 has been used in this study. Bank data are collected from bank financial reports, which have been audited, whereas macro-data are collected from the IMF 
website. The panel data (Blundell \& Bond, 1998) are not consistent because some banks have just merged together, or some banks are under special supervision of the Central Bank of Vietnam, or some banks were established after 2007. This study applies the two-step GMM for analysis in order to estimate the broad and past impacts of bank profitability and risk. Endogeneity and serial correlation in the models will be eliminated by the two-step GMM. Bank capital is considered as endogenous variable, whereas controlled variables are considered as exogenous ones. Lagged differences of endogenous variables are added to instruments at different moments. Based on the studies of Lee and Hsieh (2013), Ayadin and Karakaya (2014), and Jabra et al. (2017), the following research models are proposed in this paper in order to examine the impacts of bank capital on profitability and risk of commercial banks in Vietnam from the period 2007 to 2018 :

$$
\begin{aligned}
& \pi_{\mathrm{it}}=\alpha_{0}+\alpha_{1} \pi_{\mathrm{it}-1}+\alpha_{2} \mathrm{CAP}_{\mathrm{it}}+\alpha_{3} \mathrm{~F}_{\mathrm{it}}+\gamma_{\mathrm{i}}+\varepsilon_{\mathrm{it}}, \\
& R_{\mathrm{it}}=\beta_{0}+\beta_{1} R_{\mathrm{it}-1}+\beta_{2} \mathrm{CAP}_{\mathrm{it}}+\beta_{3} F_{\mathrm{it}}+\mu_{\mathrm{i}}+\lambda_{\mathrm{it}},
\end{aligned}
$$

where $\pi_{\mathrm{it}}$ is the bank profitability that is estimated by return on assets (ROA), return on equity (ROE), and net interest margin (NIM). $R_{\text {it }}$ is a bank risk that is estimated by the rate of nonperforming loans to total gross loans (NPL) and the rate of loan loss reserve to total assets (LLR). The definition of other variables is provided in Table 1.

Table 1

\begin{tabular}{|c|c|c|c|}
\hline \multirow[t]{2}{*}{ Group } & \multicolumn{2}{|c|}{ Variable } & \multirow{2}{*}{$\begin{array}{l}\text { Definition } \\
\text { Net income to total assets }\end{array}$} \\
\hline & ROA & Return on assets & \\
\hline \multirow[t]{2}{*}{ Bank profitability } & ROE & Return on equity & Net income to common stockholder equity \\
\hline & NIM & Net interest margin & Return on bank investment to interest expenses \\
\hline \multirow{2}{*}{ Bank risk } & LLR & Loan loss reserve ratio & Loan loss reserve to total assets \\
\hline & NPL & Non-performing loan ratio & Non-performing loans to total gross loans \\
\hline \multirow{2}{*}{ Bank capital } & ER & Equity ratio & Owners' equity to total assets \\
\hline & EQT & Equity level & Natural logarithm of owners' equity \\
\hline \multirow{6}{*}{ Controlled variables } & NLTA & Net loans to assets ratio & Total outstanding loans to total assets \\
\hline & DEP & Deposit ratio & Total deposits to total assets \\
\hline & LIQ & Liquidity ratio & Current assets to total assets \\
\hline & INF & Inflation rate & $\left(\mathrm{CPI}_{\mathrm{t}+1}-\mathrm{CPI}_{\mathrm{t}}\right) / \mathrm{CPI}_{\mathrm{t}}$ \\
\hline & GDP & GDP growth & $\left(\mathrm{GDP}_{\mathrm{t}+1}-\mathrm{GDP}_{\mathrm{t}}\right) / \mathrm{GDP}_{\mathrm{t}}$ \\
\hline & M2 & Money supply growth & $\left(\mathrm{M} 2_{\mathrm{t}+1}-\mathrm{M} 2_{\mathrm{t}}\right) / \mathrm{M} 2_{\mathrm{t}}$ \\
\hline
\end{tabular}

Variable definitions

The correlation of variables shows how variables are correlated. Table 2 presents the correlation between dependent variables.

Table 2

Correlation of dependent variables

\begin{tabular}{lrrrr}
\hline & NIM & ROA & ROE & \\
\hline NIM & 1.0000 & & & \\
ROA & 0.6022 & 1.0000 & & \\
ROE & 0.4311 & 0.7310 & 1.0000 & \\
LLR & 0.4955 & 0.0755 & 0.0877 & \\
NPL & -0.0759 & -0.2763 & -0.2960 & 1.0000 \\
\hline
\end{tabular}

Source: Author's calculation

The correlation between NIM, ROA, and ROE is observed to be high and positive because they all estimate bank profitability. Concurrently, the correlation between LLR and NPL is estimated to be positive and low. This low correlation can be attributed to the transactions between commercial banks and Vietnam Asset Management Company (VAMC), a state-owned company that buys and sells nonperforming debts of banks and other financial institutions. In other words, commercial banks may sell nonperforming loans to VAMC and receive noninterest bonds from the VAMC. Commercial banks have no longer nonperforming loans in the balance sheet once nonperforming loans are sold. However, these banks have to use their profit as loan loss reserve for $20 \%$ of nonperforming loans every year, which are sold to VAMC by banks. Thus, the nonperforming loan ratio decreases year by year but the loan loss reserve ratio remains stable. Table 3 demonstrates the correlation between dependent variables.

Table 3

\begin{tabular}{|c|c|c|c|c|c|c|c|c|}
\hline & ER & EQT & NLTA & DEP & LIQ & INF & GDP & M2 \\
\hline ER & 1.0000 & & & & & & & \\
\hline EQT & -0.534 & 1.000 & & & & & & \\
\hline NLTA & -0.101 & 0.154 & 1.000 & & & & & \\
\hline DEP & -0.383 & -0.041 & 0.211 & 1.000 & & & & \\
\hline LIQ & 0.252 & -0.366 & -0.342 & -0.121 & 1.000 & & & \\
\hline INF & 0.296 & -0.310 & -0.152 & -0.240 & 0.304 & 1.000 & & \\
\hline GDP & -0.145 & -0.024 & 0.128 & 0.220 & -0.084 & -0.255 & 1.000 & \\
\hline M2 & 0.187 & -0.312 & 0.021 & 0.053 & 0.311 & -0.066 & 0.150 & 1.0000 \\
\hline
\end{tabular}

Correlation of dependent variables 
According to Table 3, two main variables, ER and EQT, are negatively correlated. This happens when commercial banks increase the equity which consequently increases the total assets. However, the rate of equity to total assets decreases when the total assets increases faster than equity. Therefore, in the case of commercial banks of Vietnam, the increase in equity results in a decrease in the rate of equity and the liquidity ratio but it increases the loan ratio.

\subsection{Estimation results}

In this subsection, the results of the impacts of bank capital on profitability and risk are presented. The effects on profitability are analyzed in the first part and the effects on risk are discussed in the second part. The results of the two-step GMM are presented in Tables 4 and 5. In these tables, the Sargan test is applied to examine the overidentification restriction of instruments and the Arellano-Bond test is applied for the serial correlation estimation. Both tests indicate that the results are consistent and reasonable for all estimations.

\section{Table 4}

Bank profitability

\begin{tabular}{|c|c|c|c|c|c|c|}
\hline \multirow[b]{2}{*}{$\overline{\mathrm{ROA}_{\mathrm{t}-1}}$} & \multicolumn{2}{|c|}{$\mathrm{ROA}$} & \multicolumn{2}{|c|}{ ROE } & \multicolumn{2}{|c|}{ NIM } \\
\hline & $0.139 * * *$ & $0.374 * * *$ & & & & \\
\hline $\mathrm{ROE}_{\mathrm{t}-1}$ & & & $0.138^{*}$ & $0.154 * * *$ & & \\
\hline NIM $_{t-1}$ & & & & & $0.877 * * *$ & $0.768 * * *$ \\
\hline ER & $-0.081 * *$ & & $-0.602 * * *$ & & 0.140 & \\
\hline EQT & & $-0.004 * *$ & & $-0.111 * * *$ & & -0.024 \\
\hline NLTA & $0.043 * * *$ & $0.055 * * *$ & $0.408 * * *$ & $0.627 * * *$ & $0.053 * * *$ & $0.079 * * *$ \\
\hline DEP & $-0.033 * * *$ & $-0.039 * * *$ & $-0.625 * * *$ & $-0.566 * * *$ & 0.009 & $-0.041^{*}$ \\
\hline LIQ & $0.009^{*}$ & 0.003 & $0.152 * * *$ & $0.232 * * *$ & 0.014 & 0.047 \\
\hline INF & $-0.029 * * *$ & $-0.012 * * *$ & -0.031 & -0.020 & -0.090 & $-0.055^{*}$ \\
\hline GDP & $0.240 * * *$ & $0.081 * * *$ & $2.442 * * *$ & $1.984 * * *$ & 0.167 & 0.013 \\
\hline M2 & -0.003 & $0.008 *$ & $0.311 * * *$ & $0.127 * * *$ & $-0.081 * * *$ & $-0.094 * * *$ \\
\hline Observations & 288 & 288 & 288 & 288 & 288 & 288 \\
\hline Instruments & 25 & 30 & 30 & 30 & 17 & 17 \\
\hline Sargan test & 0.210 & 0.970 & 0.280 & 0.310 & 0.560 & 0.340 \\
\hline $\begin{array}{l}\text { Arellano-Bond test } \\
\text { AR (2) }\end{array}$ & 0.587 & 0.125 & 0.720 & 0.470 & 0.080 & 0.110 \\
\hline
\end{tabular}

First, bank profitability is estimated by its capital. As the equity ratio and the equity level are used to measure bank capital, the effects are observed to be consistent. Bank capital negatively impacts profitability when bank profitability is measured by using ROA and ROE. This result is in agreement with those of Altunbas et al. (2007) and Goddard et al. (2013), who claim that banks with a higher equity ratio would not receive the advantage of income tax as well as will have to pay a higher opportunity cost for cash holding. Thus, bank profitability will be reduced with a higher equity ratio. However, the significant impacts of bank capital on profitability are not found when NIM is used as a proxy of bank profitability (Lee \& Hsieh, 2013).

Table 5

Bank risk

\begin{tabular}{|c|c|c|c|c|}
\hline \multirow[b]{2}{*}{$\mathrm{NPL}_{\mathrm{t}-1}$} & \multicolumn{2}{|c|}{ NPL } & \multicolumn{2}{|c|}{ LLR } \\
\hline & $0.315 * * *$ & $0.115^{* *}$ & & \\
\hline $\mathrm{LLR}_{\mathrm{t}-1}$ & & & $0.121 * *$ & $0.154 * *$ \\
\hline ER & $-0.168 * *$ & & -0.009 & \\
\hline EQT & & $0.015 * * *$ & & -0.001 \\
\hline NLTA & -0.002 & -0.010 & -0.002 & -0.001 \\
\hline DEP & $-0.034 * *$ & 0.020 & 0.003 & 0.002 \\
\hline LIQ & $-0.030 * * *$ & 0.022 & $-0.026 * *$ & $-0.023 * *$ \\
\hline INF & $-0.098^{*}$ & 0.021 & $-0.011 * *$ & $-0.021 * *$ \\
\hline GDP & $-0.563 * * *$ & $-0.564 * * *$ & $-0.054 * *$ & $-0.072 * *$ \\
\hline M2 & $-0.065 * *$ & -0.034 & $-0.018 * * *$ & $-0.019 * * *$ \\
\hline Observations & 288 & 288 & 288 & 288 \\
\hline Instruments & 20 & 20 & 20 & 20 \\
\hline Sargan test & 0.280 & 0.215 & 0.120 & 0.158 \\
\hline Arellano-Bond test AR (2) & 0.171 & 0.082 & 0.370 & 0.350 \\
\hline
\end{tabular}

Second, the impacts of bank capital on risk depend on the factor that is used for bank risk. The effects are observed to be significant when the nonperforming loan ratio is used for bank risk, whereas no impact is observed when the loan loss reserve ratio is used. The equity ratio negatively affects bank risk and this result is in agreement with those of Jacques and Nigro (1997), Altunbas et al. (2007), Agusman et al. (2008), Lee and Hsieh (2013), and Jabra et al. (2017). However, the equity level shows 
positive impacts on bank risk. In Vietnam, banks have to promote their sale and investment when they increase their capital levels, which may lead to higher nonperforming loans. In reality, in order to fulfill the commitment of capital level, commercial banks increase their capital during the period 2008-2010 and as a result, the nonperforming loan ratio sharply increased in the next period of 2011-2013, peaking 4\% in 2012. The impacts of controlled variables on bank profitability and risk are estimated to be relatively consistent with other studies. The net loans to assets ratio demonstrates a positive impact on bank profitability (Iannotta et al., 2007; Lee \& Hsieh, 2013; Ayaydin \& Karakaya, 2014; Menicucci \& Paolucci, 2015; Jabra et al., 2017) because until now offering loans is the primary source of bank income in Vietnam, like most developing economies. According to this study, NLTA does not show a significant impact on bank risk and this result is partly in agreement with those of Lee and Hsieh (2013) and Jabra et al. (2017). The deposit ratio shows significant negative impacts on both bank profitability and risk. A higher deposit ratio creates more pressure on banks to use deposits effectively. Similarly, a rapid increase in deposit may result in a higher level of interest paid, which will reduce profitability. On the other hand, an increase in the deposit ratio may ensure low reserve from banks or may increase bank liquidity, which in turn may reduce the operational risk. In general, the liquidity ratio shows positive impacts on profitability and negative impacts on risk. For short-term sale, such as interbank loans, short-term loans, etc., high liquid assets may be used. Hence, these short-term sales can make banks more effective. Macroindicators are positively related to bank profitability and risk. Inflation shows negative impacts on bank profitability (Naceur \& Kandil, 2009; Lee and Hsieh, 2013). Similarly, unexpected inflation can make banks inactive by adjusting their interest rates, which may reduce the net interest margin of banks. In this period, inflation was under control in Vietnam, indicating that moderate inflation is a favorable condition for economic development, which in turn reduces bank risk. A higher rate of GDP growth can lead to higher bank profitability and lower bank risk. The improvement in the economy will generate more demand in the capital market which will have positive impacts on bank operation or bank profitability. Flamini et al. (2009), Lee and Hsieh (2013), and Jabra et al. (2017) show similar results. Finally, money supply (M2) shows positive impacts on ROA and ROE of banks, whereas M2 negatively affects the NIM of banks. An expansionary monetary policy not only improves ROA and ROE of banks but also increases the cost of the marginal interest rate. In addition, the expansion of loans can create higher cost of reserve, which reduces the net interest margin of banks.

\section{Conclusion}

In this paper, the impacts of bank capital on profitability and risk in Vietnam were empirically investigated from the period 2007 to 2018. The equity ratio and the equity level were considered as bank capital. ROA, ROE, and NIM were used to measure bank profitability, whereas the loan loss reserve ratio and the nonperforming loan ratio were used to measure the proxy of bank risk. In this paper, data of 35 commercial banks were merged into an unbalanced panel sample by collecting bank data from the audited balance sheet. In addition, inflation, GDP growth, and M2 were also used as controlled variables in the model. The twostep GMM, which controls endogeneity and serial correlation, was used to estimate the impacts. Bank capital, in both equity ratio and equity level, has shown significant negative impacts on bank profitability (ROA and ROE), whereas it showed no impacts on NIM. Moreover, the impacts of bank capital on risk also depend on how capital and risk are measured. Bank capital was found to have no impact on risk if the loan loss reserve ratio was considered bank risk. If the nonperforming loan ratio is used to measure risk, the equity ratio shows significant negative impacts on risk whereas the equity level shows positive impacts on risk. The impacts of bank capital on profitability and risk may propose some implications. First, it depends on what banks need, high profitability, and high risk or vice versa, in the case of commercial banks. Banks can reduce the equity ratio or the equity level if commercial banks want to raise their profit. Moreover, banks can buy their stocks for reserve or can increase deposits in order to decrease the equity ratio. However, a decrease in the equity ratio may lead to higher bank risk. Banks can reduce the deposit ratio or increase the capital level if banks want to reduce their risk. Banks require performing well in investment risk management in order to lower their risk. In order to obtain the targeted capital ratio, banks also increase deposits nowadays when they increase their equity. Second, the nonperforming loan ratio may increase sharply, as happened in the past, if the policymakers instruct banks to increase their capital in a short time. Therefore, policymakers should instruct every bank to outline their own procedure for managing risk management and gradually fulfilling the global requirements. In addition, policymakers should also draw a roadmap for banks in order to increase their bank capital. Simultaneously, banks should also develop their risk management system in order to strengthen their ability to control the increasing risk.

\section{References}

Agusman, A., Monroe, G. S., Gasbarro, D., \& Zumwalt, J. K. (2008). Accounting and capital market measures of risk: Evidence from Asian banks during 1998-2003. Journal of Banking and Finance, 32(4), 480-488.

Alper, D., \& Anba, A. (2011). Bank specific and macroeconomic determinants of comercial bank profitability: Empirical evidence from Turkey. Journal of Business and Economics Research, 2(2), 139 - 152.

Altunbas, Y. S., Carbo, E., Gardener, P. M., \& Molyneux, P. (2007). Examining the relationships between capital, risk, and efficiency in European banking. European Financial Management, 13(1), 49-70.

Arellano, M., \& Bover, O. (1995). Another look at the instrumental-variable estimation of errorcomponents. Journal of Econometrics, 68(1), 29-52. 
Athanasoglou, P. P., Delis, M. D., \& Staikouras, C. K. (2006). Determinants of bank profitability in the South Eastern European Region. Bank of Greece, Working paper No. 25.

Ayaydin, H., \& Karakaya, A. (2014). The effect of bank capital on profitability and risk in Turkish banking. International Journal of Business and Social Science, 5(1), 252-271.

Berger, A. N. (1995). The relationship between capital and earnings in banking. Journal of Money, Credit and Banking, 27(2), $432-456$.

Blundell, R., \& Bond, S. (1998). Initial conditions and moment restrictions in dynamic panel data models. Journal of Econometrics, 87, 115-143.

Dimitrios, P. L., Angelos, T. V., \& Vasilios, L. M. (2010). Macroeconomic and bank specific determinates of nonperforming loans in Greece's. Bank of Greece. Working paper No. 118.

Doytch, N., \& Uctum, M. (2011). Does the worldwide shift of FDI from manufacturing to services accelerate economic growth? A GMM estimation study. Journal of International Money and Finance, 30(3), 410-427.

Flamini, V., McDonald, C., \& Schumacher, L. (2009). The determinants of commercial bank profitability in Sub Saharan Africa. International Monetary Fund, Working paper, No 9.

Goddard, J., Molyneux, P., Wilson, J. O. S., \& Liu, H. (2013). Do bank profits converge? European Financial Management, $19(2), 345-365$.

Iannotta, G., Nocera, G., \& Sironi, A. (2007). Ownership structure, risk, and performance in the European banking industry. Journal of Banking and Finance, 31(7), 2127-2149.

Jabra, W. B., Mighri, Z., Mansouri, F. (2017). Bank capital, profitability and risk in BRICS banking industry. Global Business and Economics Review, 19(1), 89-119.

Jacques, K. T., \& Nigro, P. (1997). Risk-Based Capital, Portfolio Risk and Bank Capital: A Simultaneous Equations Approach. Journal of Economics and Business, 49, 533-547.

Jafari, M. K. A., \& Alchami, M. (2014). Determinants of bank profitability: Evidence from Syria. Journal of Applied Finance \& Banking, 4(1), 17-45.

Lee, C. C., \& Hsieh, M. F. (2013). The impact of bank capital on profitability and risk in Asian Banking. Journal of International Money and Finance, 32, 251-281.

Menicucci, E., \& Paolucci, G. (2016). The determinants of bank profitability: empirical evidence from European banking sector. Journal of Financial Reporting and Accounting, 14(1), 86-115.

Muda, M., Shaharuddin, A., \& Embaya, A. (2013). Comparative analysis of profitability determinants of Domestic and Foreign Islamic banks in Malaysia. International Journal of Economics and Financial Issues, 2(2), 559-569.

Naceur, S B. \& Kandil, M. (2009). The impacts of capital requirements on banks' cost of intermediation and performance: The case of Egypt. Journal of Economics and Business, 61(1), 70-89.

Nguyen, T. H. V., \& Le, P. T. D. T. (2016). Effects of Bank Capital on Profitability and Credit Risk: The Case of Vietnam's Commercial Banks. Journal of Economic Development, 23(4), 117-137.

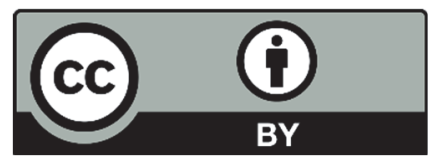

(C) 2020 by the authors; licensee Growing Science, Canada. This is an open access article distributed under the terms and conditions of the Creative Commons Attribution (CC-BY) license (http://creativecommons.org/licenses/by/4.0/). 